The Turkish Online Journal of Design, Art and Communication - TOJDAC

ISSN: 2146-5193, September 2018 Special Edition, p.1044-1056

\title{
GAMIFICATION FOR THE MOTIVATION OF SCIENTIFIC AND PEDAGOGICAL STAFF
}

\author{
Andrey V. KIRILLOV \\ Russian State Social University, Russia \\ Aleksandr V. MELNICHUK \\ Russian State Social University, Russia \\ Valery V. BONDALETOV \\ Russian State Social University, Russia \\ Natalia P. LI \\ Russian State Social University, Russia \\ LTD HeadHunter, Russia \\ Marina A. LVOVA \\ LTD HeadHunter, Russia
}

\begin{abstract}
In the conditions of reforming the Russian higher school, the introduction of innovative technologies is the most important trend of modern transformations. One of the trends is the introduction of game elements in the system of motivation of the personnel, including the teaching staff. Given the heterogeneity of the teaching environment, which is based on different values of generations, the issue of diagnosing the attitude of teachers of different ages to gaming is quite relevant. The study of this issue allowed the authors to determine a number of contradictions: i) despite intergenerational differences, modern teachers equally demonstrate positive attitude towards gaming technologies; ii) despite the positive attitude of most teachers to gamification, the introduction of gaming technology into the motivation system is fragmentary. In the study, the authors used the methods of generalization and comparison, systematic sociological and statistical analysis. Based on the results of the study and conducted analysis, the authors identified barriers and developed recommendations for the introduction of gaming technologies in the system of motivating teachers.
\end{abstract}

Keywords: gamification, intergenerational relations, motivation of university teachers.

\section{INTRODUCTION}

The sharp actualization in the world community of interest in the functioning of the basic social institution, the education system, is explained by its growing role in the development of all social spheres of any national community and above all the economy. Today, the education system is tightly connected with the goals and objectives of developing a market economy, which is also a timely response to the challenges of the 21 st century. The oncoming information and technological era require the universal modernization of the education system on all levels (Egorychev, Mardochaev, Rybakova, Fomina, \& Sizikova, 2014).

Today, the world community clearly shows the tendencies associated with the processes of integration of many social processes that are the condition for the sustainable development of any national community, including the education system. In this situation, the system of Russian education requires modernization, where almost all its components (goals, content, methodological and technological support, mechanisms for supporting and developing the creative potential of teachers and students, etc.) should be affected (Egorychev, Mityaeva, Fomina, \& Khovanskaya, 2017).

The modernization of the Russian higher school, accompanied by the dynamic development of the educational services market and, as a result, the increased competition of educational institutions, 
requires managers of any level to use the most effective forms and methods of disclosing the potential of the faculty through the up-to-date HR technologies.

The competitiveness of the institution is determined by the characteristics of personnel; first, these are the interest and ability of a teacher of higher education to maintain the active pace of his or her research activity (Rogach, Frolova, \& Ryabova, 2017). In this context, the value-normative (the formation and legitimation of standards, samples of role expectations, values of research activities) and motivational aspects (the formation of conditions and specific incentives that contribute to the effective construction of the teachers' careers, providing a satisfactory ratio between the costs and rewards of employees) are of high importance (Rogach, Ryabova, \& Frolova, 2017).

However, insufficient attention has been paid to the purposeful actions of the higher educational institution (university) management focused on involving faculty in applying current technologies, to retain the most talented of them (Vinichenko, Taridi Kasbi Ridho, Kirillov, Makushkin, \& Melnichuk, 2017; Melnichuk, 2017). According to today's studies, no more than a third of university professors participate in innovation processes (Sheregi, \& Kirillov, 2017). And according to HeadHunter, in the 10 -year perspective, the importance of attracting talents will only grow. At the same time, demographic factors may exacerbate competition in the struggle for talent (HeadHunter, 2018).

The situation is aggravated by the fact that today priority is given to universities that can be characterized in such categories as: innovative, first, leading, advanced, "carrying an international weight", etc. At the same time, the social status of teachers is changing and not always improving (Ilina, Oseev, Vinichenko, Kirillov, Kaurova, \& Nakhratova, 2018). It is not possible to achieve such results without a purposeful work of the university management staff in order to ensure the motivation of scientific and pedagogical personnel. This is especially true in the context of the continuous reorganization of the training system (Vinichenko, Kirillov, Maloletko, Frolova, \& Vinogradova, 2018).

There is no doubt that exclusively external, material rewards cannot ensure sufficient effectiveness of motivation and retain staff in the up-to-date economy characterized by high competition for labor and the need for innovation, for which internal motives related to the content of labor, self-realization, and satisfaction from their own achievements, are much more decisive (Dieva, 2017). Gamification, that is, the application of game-design elements and game principles in nonplayer processes (Zichermann, \& Linder, 2014, p. 5) is considered to be one of the innovative management technologies involved in the mechanisms of internal motivation. In turn, the impact on internal motivation mechanisms through the application of game techniques can become an important factor in retaining valuable employees, increasing their loyalty, and will help them to feel special (Burke, 2014).

It is worth noting that the idea itself is not new: in the Soviet Union, such motivational tools as socialist competitions, passing distinctions were actively used. Great experience in this matter has been accumulated abroad, including the university science. In particular, the University of Pennsylvania (USA) has formed a serious scientific school Gamification in personnel management (Werbach, \& Hunter, 2015).

The contemporary toolkit of gamification is undergoing significant changes as a result of improving the management and rapid development of information technology (Fedorishcheva, 2016). In the system of gamification, three following main groups of game techniques are distinguished: competitive techniques; Win-Win, aimed at providing all employees with operational feedback on performance and stimulating their development; visualization techniques (Valeev, \& Kamasheva, 2016; Melnichuk, 2016).

Currently, issues of gamification, including those affecting the increase of staff motivation, attract attention of many foreign and Russian researchers (Kozina, 2015; Melnichuk, 2015; Shtonda, 2017; Krasovsky, Soroko, Shemonchuk, Bondaletov, Baklanov, \& Solodova, 2018), a wide range of practitioners. So, according to the HeadHunter company, in 2016 every second company in the framework of the HR branding task carried out a study of employee involvement, and every third company introduced the system of awards of the best employees and the grading of staff (Digital Literacy in HR: 2016 Trends, https: // hhcdn.ru/file/16397049.pdf). 
An increasing demand for the gamification technologies of employee motivation is shown by one of the most prestigious Russian competitions in HR management, HR Brand Award, established by HeadHunter. In 2006, only a few projects in the field of gamification of nonmaterial incentives for personnel were submitted for the competition; in 2018, among the projects nominated for this award, a third was related to these issues, in particular, the Euroset's EUROFORCE Business Game; HEINEKEN Russia's Leadership and Talent Development Program DRIVE YOUR FUTURE; Binbank's Aerobatics Competition; League of Professionals of Deloviye Linii Company; Megafon's MegaConsultant Project; From Operators to Managers by Tele2, quests, colleague dueling, the battle for the best title by target indicators, and many others.

The PBL Triad (points, badges, leaderboards) is one of the most common motivational gamification technologies. It should be noted that in 2012-2015 a lot of attention was paid to the application of these tools in higher educational institutions of the Russian Federation, but now there is a decline in their use. The authors of this paper have set the goal to understand the reasons for this recession, in the possibility and expediency of expanding the application of gamification techniques in motivating faculty members.

\section{METHODS}

To determine the nature of the views on creating favorable conditions for increasing the motivation of scientific and pedagogical staff through gamification, a methodology for sociological study was developed, based on general scientific methods, research and experimental measures. The sociological methods were applied (included observation, interviewing, questioning), as well as statistical methods, methods of confrontation, comparison, content analysis, visual and system analysis. In the course of the study, a mass questionnaire survey was conducted among the faculty members on a representative sample; the focus groups in the main social and professional groups of teachers, as well as a survey of experts by the method of face-to-face semi-formalized interviews.

\section{Respondents}

The paper is based on the sociological survey data conducted in 2017-2018 at the Russian State Social University. One of the study objectives was to find out the possibility of using gamification for increasing the motivation of the scientific and pedagogical staff.

The study was selective according to the strategy of forming an empirical object. It was regional according to the scale of extrapolation of results. Information carriers (respondents) were teachers of state universities of the Russian Federation (Altai State Technical University named after I.I. Polzunova, Belgorod University of Cooperation, Economics and Law, Voronezh State University, Eastern Economic and Legal Humanitarian Academy, State University of Management, Far Eastern Federal University, Kemerovo State University, Kuban State University, Kursk State University, Lipetsk State Technical University, Moscow Aviation Institute, Moscow State Institute of International Relations (University) of the MFA of Russia, Moscow State University named after M.V. Lomonosov, Moscow Technological University, Yaroslav-the-Wise Novgorod State University, Omsk State University named after F.M. Dostoevsky, Orenburg State University, the Russian Academy of National Economy and Public Service, the Russian State Social University, Plekhanov Russian University of Economics, Samara State Technical University, Samara State University of Communications, St. Petersburg State University of Economics, North Caucasus Federal University, Surgut State University, Ural State University of Communications, Ural Federal University, Finance University under the Government of the Russian Federation, Chelyabinsk State University). The questionnaire used a quota sample, formed according to 7 characteristics: sex, age, job status, academic degree, academic rank, teaching experience and work experience in this institution, which included 572 people.

The age differentiation of the respondents is shown in Table 1.

Table 1. Age differentiation of respondents

\begin{tabular}{|c|l|}
\hline Age & Number of respondents (\%) \\
\hline
\end{tabular}

Submit Date: 10.07.2018, Acceptance Date: 22.08.2018, DOI NO: 10.7456/1080SSE/144

Research Article - This article was checked by Turnitin

Copyright (C) The Turkish Online Journal of Design, Art and Communication 
The Turkish Online Journal of Design, Art and Communication - TOJDAC

ISSN: 2146-5193, September 2018 Special Edition, p.1044-1056

\begin{tabular}{|c|c|}
\hline under 35 & 22.4 \\
\hline medium aged $-35-50$ & 45.5 \\
\hline over 50 & 32.1 \\
\hline
\end{tabular}

The gender differentiation of the respondents showed some predominance of women (Table 2).

Table 2. Gender differentiation of respondents

\begin{tabular}{|c|c|}
\hline Sex & Number of respondents (\%) \\
\hline female & 75.5 \\
\hline male & 24.5 \\
\hline
\end{tabular}

The majority of respondents, who took part in the questionnaire, occupied the post of Assistant Professor (Table 3).

Table 3. Job status differentiation of respondents

\begin{tabular}{|c|c|}
\hline Title & Number of respondents (\%) \\
\hline Assistant & 5.26 \\
\hline Teacher & 7.02 \\
\hline Senior Teacher & 14.91 \\
\hline Assistant Professor & 65.79 \\
\hline Professor & 14.91 \\
\hline Chairperson & 14.04 \\
\hline Dean & 3.51 \\
\hline
\end{tabular}

Candidates of science prevailed in the characteristics of the scientific degree (Table 4).

Table 4. Scientific degree differentiation of respondents

\begin{tabular}{|c|c|}
\hline Degree & Number of respondents (\%) \\
\hline No degree & 22.4 \\
\hline Candidate of Sciences & 59.4 \\
\hline Doctor of Science & 18.2 \\
\hline
\end{tabular}

Most respondents had the academic rank of Assistant Professor (Table 5).

Table 5. Academic rank differentiation of respondents

\begin{tabular}{|c|c|}
\hline Academic rank & Number of respondents (\%) \\
\hline No rank & 40.5 \\
\hline Assistant Professor & 47.6 \\
\hline Professor & 11.9 \\
\hline
\end{tabular}

The old stagers prevailed according to the pedagogical experience of work at higher education institutions and the work experience at a particular institution (Tables 6,7). 
Table 6. Differentiation of respondents according to pedagogical experience at higher educational institutions

\begin{tabular}{|c|c|}
\hline Pedagogical experience & Number of respondents (\%) \\
\hline Up to 5 years & 11.9 \\
\hline 5-10 years & 18.2 \\
\hline Over 10 years & 69.9 \\
\hline
\end{tabular}

Table 7. Differentiation of respondents according to work experience at this institution

\begin{tabular}{|c|c|}
\hline Work experience at this institution & Number of respondents (\%) \\
\hline Up to 3 years & 18.9 \\
\hline 3-7 years & 25.9 \\
\hline Over 7 years & 55.2 \\
\hline
\end{tabular}

In addition, the authors held 4 focus groups. The empirical base of the expert survey of the focus groups included as follows: heads of scientific and pedagogical staff of Moscow universities, representatives of age cohorts. 38 experts were interviewed.

\section{Procedure}

As a method of collecting primary sociological information, the survey used a mass survey of university professors in the technique of online questioning in a specially developed questionnaire. The authors' questions were used in the questionnaire.

The study used a spontaneous method of forming a sample of respondents with a posteriori disproportionate quota. Given the lack of representativeness of spontaneous online sampling, and also implementing a strategy of comparative study rather than descriptive one, a sampling was formed of samples, which included approximately the same (statistically comparable) groups of respondents. The implementation of this algorithm provided a sufficient number of respondents in each group that was formed, which allowed conducting the quantitative analysis of sociological information at a statistically significant level simultaneously for many indicators of group stratification. As a result, a sample of 572 people was subject to statistical analysis.

When conducting the focus groups, the average duration of the study was 1.5 hours, the average number of participants was 10 people. Using a semi-structured guide for interviewing, the interviewer studied the opinions of the focus group participants on the gamification issues for increasing the motivation of the scientific and pedagogical staff.

\section{Data analysis}

The general procedure for processing the received verbal information was carried out according to the standard mathematical program for the processing of statistical data, SPSS/PC. The analysis and presentation of the data resulted in the construction of statistical distributions, groupings, comparisons, conjugations of the investigated features, construction of ranking priority scales and statistical extrapolation of data on indicators of subjective opinions and respondents' assessments.

When analyzing the data obtained in the focus groups, a traditional qualitative content analysis of the interview was conducted using coding categories derived from texts. The data analysis began after the first interview; transcribed interviews were examined together with additional information from notes on participants.

\section{RESULTS}

Submit Date: 10.07.2018, Acceptance Date: 22.08.2018, DOI NO: 10.7456/1080SSE/144

Research Article - This article was checked by Turnitin

Copyright (C) The Turkish Online Journal of Design, Art and Communication 


\section{The gamification technologies as tools of moral labor stimulation}

As shown by the study, moral labor incentives motivate the overwhelming majority $(89.5 \%)$ of university professors surveyed significantly even at high wages (Fig.1). Probably, this is connected not only with the need of the generation $\mathrm{Y}$ in recognizing their merits and regular feedback, and with their love for frequent, even conditional remunerations, but also with the fact that generation $\mathrm{X}$, to which veterans belong, has entered the profession and remained there not so much for mercantile reasons, but by vocation.
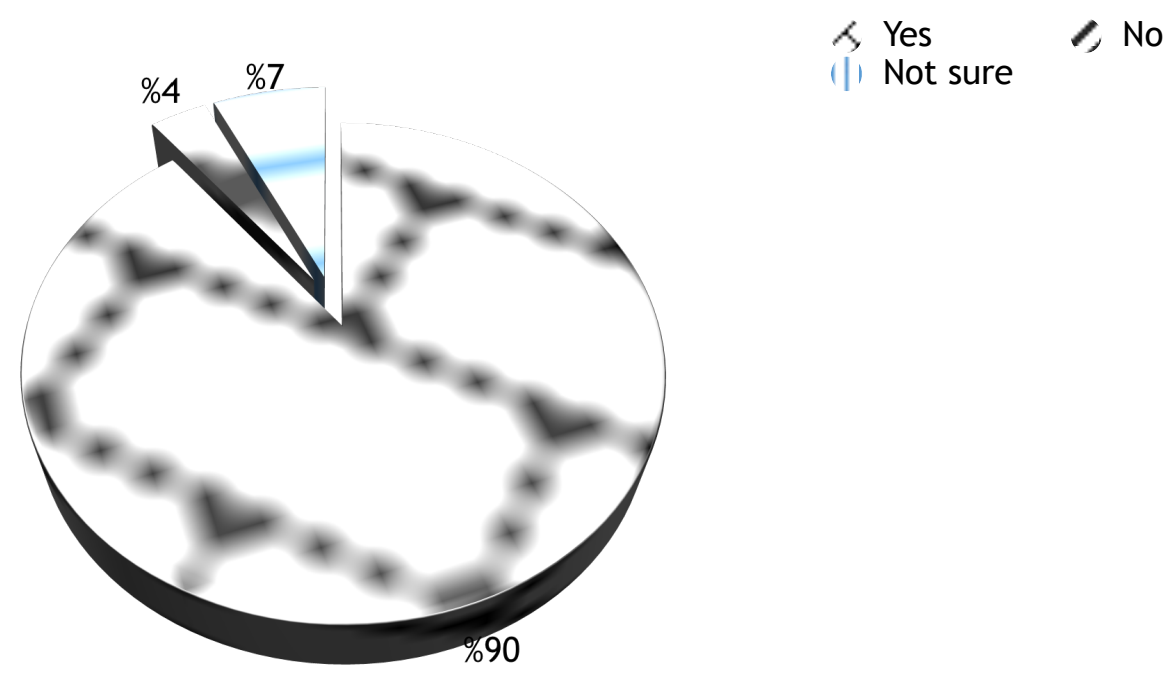

(1) Not sure No

Fig.1. Distribution of responses to the question "Is moral labor motivation important for you with a high wage?" (in \% of the number of teachers interviewed)

With a high need for moral stimulation of labor, more than half of the teachers surveyed are not satisfied with it (Fig.2). Only 9.8\% of respondents expressed complete satisfaction with moral incentives.
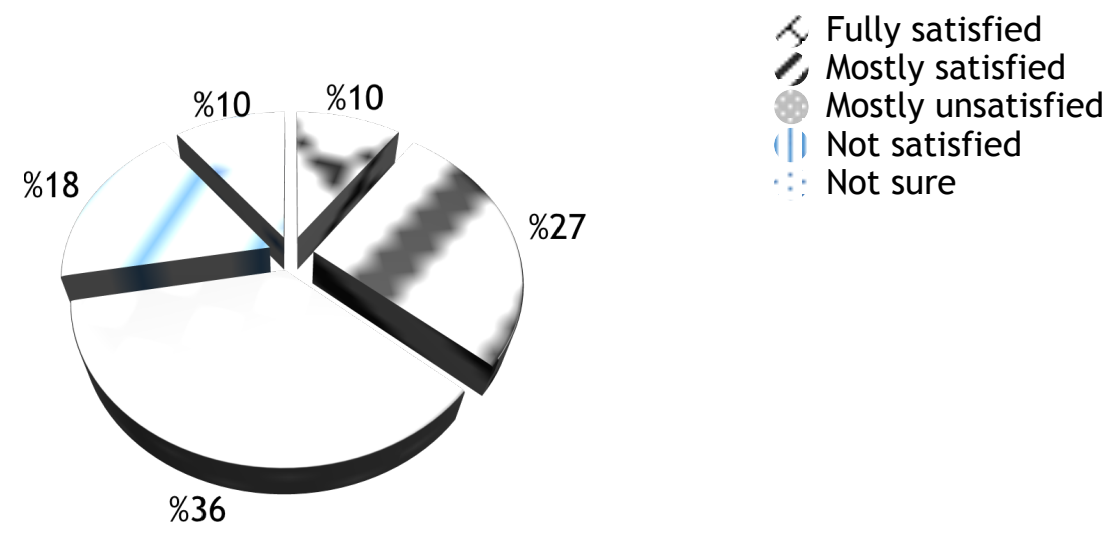

$\% 27$

Fig.2. Distribution of responses to the question "Are you satisfied with moral incentives of teachers applied at your institution?" (in \% of the number of teachers interviewed)

Among the reasons for the ineffectiveness of the moral incentive systems used at universities, the respondents most often called the rare application of encouragement, the use of the same type of moral incentives, and the clarity of the incentive criteria, as well as the dependence of incentives on relations with management; its subjectivity. One cannot ignore the teachers' claims to feedback in this matter, because it fixes the required model of a teacher's organizational behavior and stimulates him or her to perform one's duties qualitatively.

Thus, today a rather formal approach to the issue of moral incentives for teachers is observed at higher education institutions. The solution to this problem seems to be the application of gamification. 
From the data obtained in the course of the study, it follows that the gamification techniques for increasing the motivation of work are used very poorly at Russian universities (Fig.3)

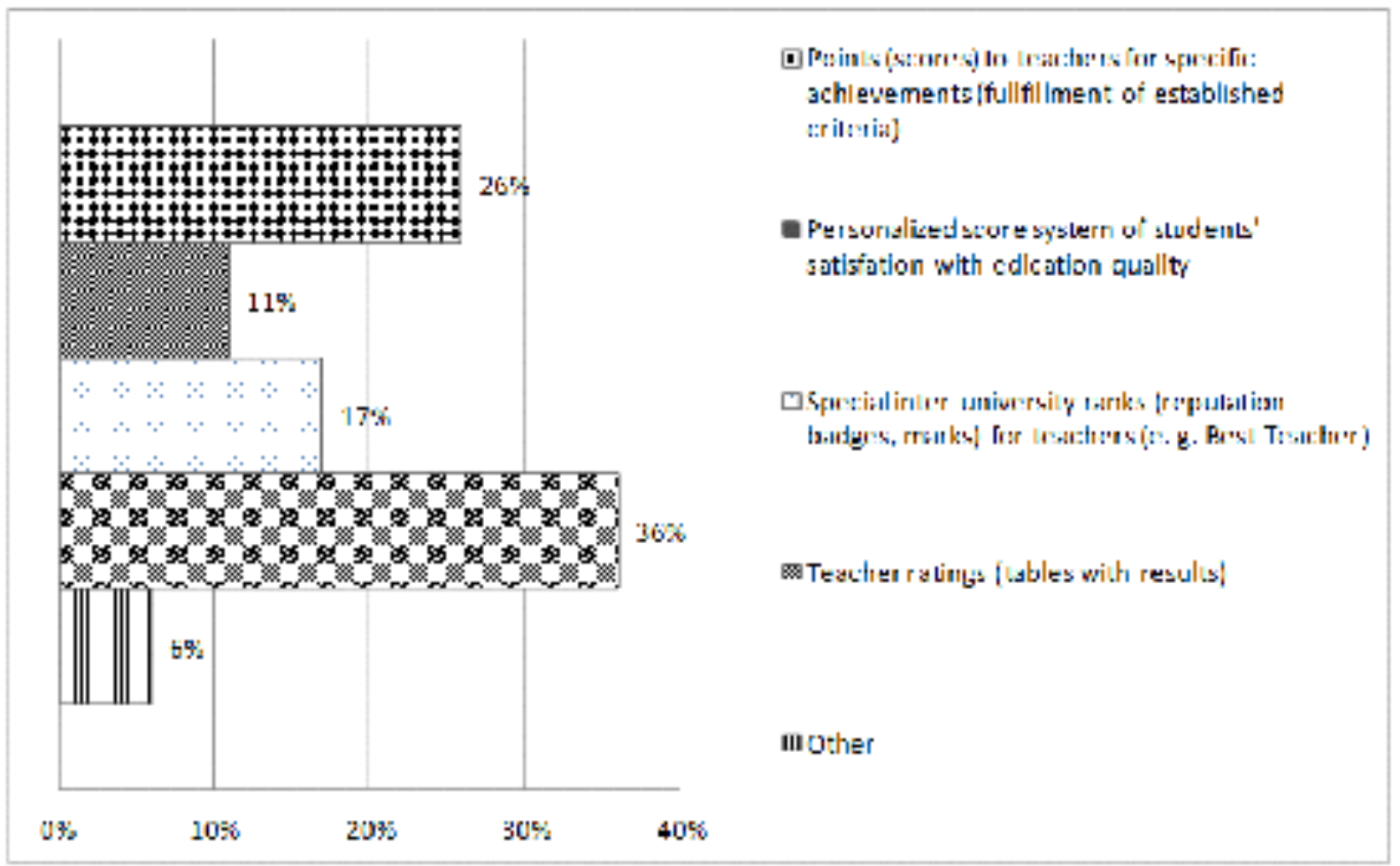

Fig.3. Distribution of responses to the question "What gamification techniques for increasing the motivation of work are applied at your institution?" (in \% of the number of respondents)

At the same time, most of the interviewed teachers support the use of the PBL system at higher education institutions for motivating scientific and pedagogical staff (Fig.4).

Would you like to see a board of honor on the university's corporate portal

Would you like to see your own achievements and achievements of your colleagues in a professional environment in

Would you like to see your visual distinctions (badges) by your photo on the uni

Do you consider it appropriate to determine the "best employee" in various types of professional activity, to assign university deg!

Fig.4. The share of affirmative responses to the questions on the use of the PBL system at higher education institutions (in \% of the number of respondents) 
In this study, the youngest and most mature cohort of respondents (Fig.4) agreed in an amazing way about the high importance of the use of the PBL system at universities for motivating scientific and pedagogical staff. Most likely, this is due to the fact that young people belong to the generation Y, who grew up playing games, and veterans came to a similar conclusion because of the wisdom and experience.

\section{Ways to expand gamification to stimulate the work of teachers}

As can be seen in Fig.5, the respondents named the low level of objectivity due to the lack of clear criteria and the complexity of the systems for calculating points (scores) for teachers for certain achievements (fulfillment of established criteria) as a main obstacle for the increasing gamification in order to stimulate the work of teachers. At the same time, the majority of respondents do not agree with the lack of interest in the subject by teachers.

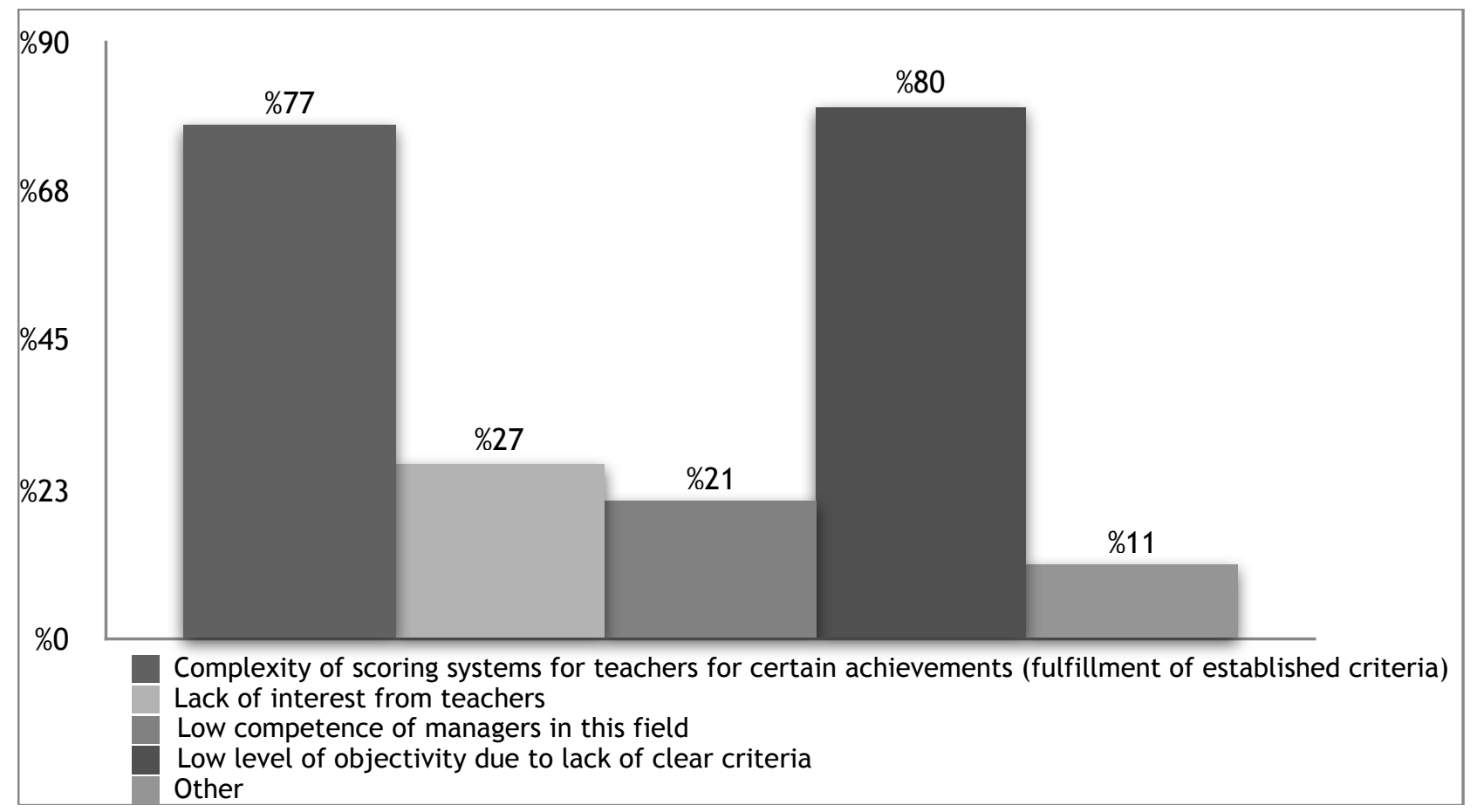

Fig.5. Distribution of responses to the question "What is the main reason that prevents the expansion of gamification in order to stimulate the work of teachers?" (in \% of the number of respondents)

In singling out the fundamental principles that should be used in gamification in order to stimulate the work of teachers, the respondents placed first the principles of simplicity and feedback; and the principle of verifiability was also often called (Fig.6). 
The Turkish Online Journal of Design, Art and Communication - TOJDAC

ISSN: 2146-5193, September 2018 Special Edition, p.1044-1056

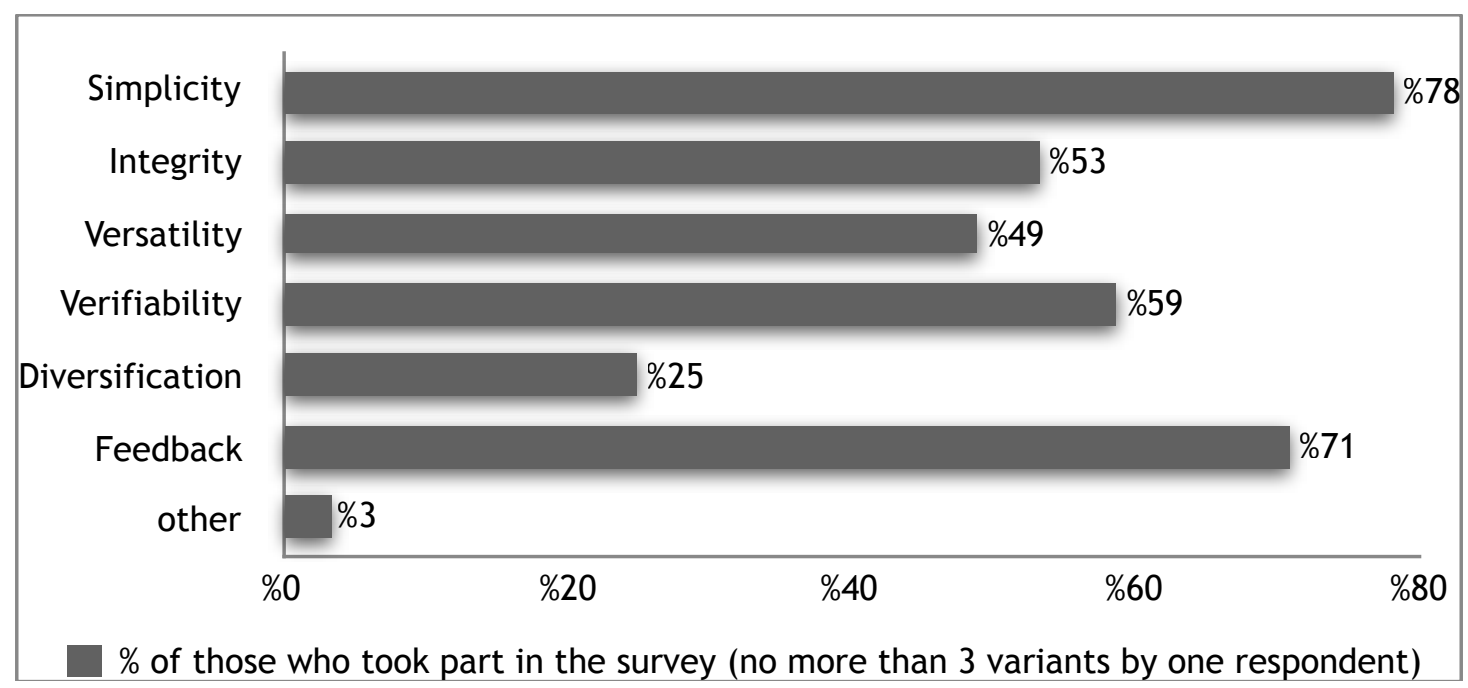

Fig.6. Distribution of respondents' answers to the question "What principles should be used to base the gamification in order to stimulate the work of teachers?" (in \% of the number of respondents)

The study showed that the younger the group of respondents, the less often they believed that the principle of verification should be used as a basis for gamification in order to stimulate the work of teachers (Fig.7).

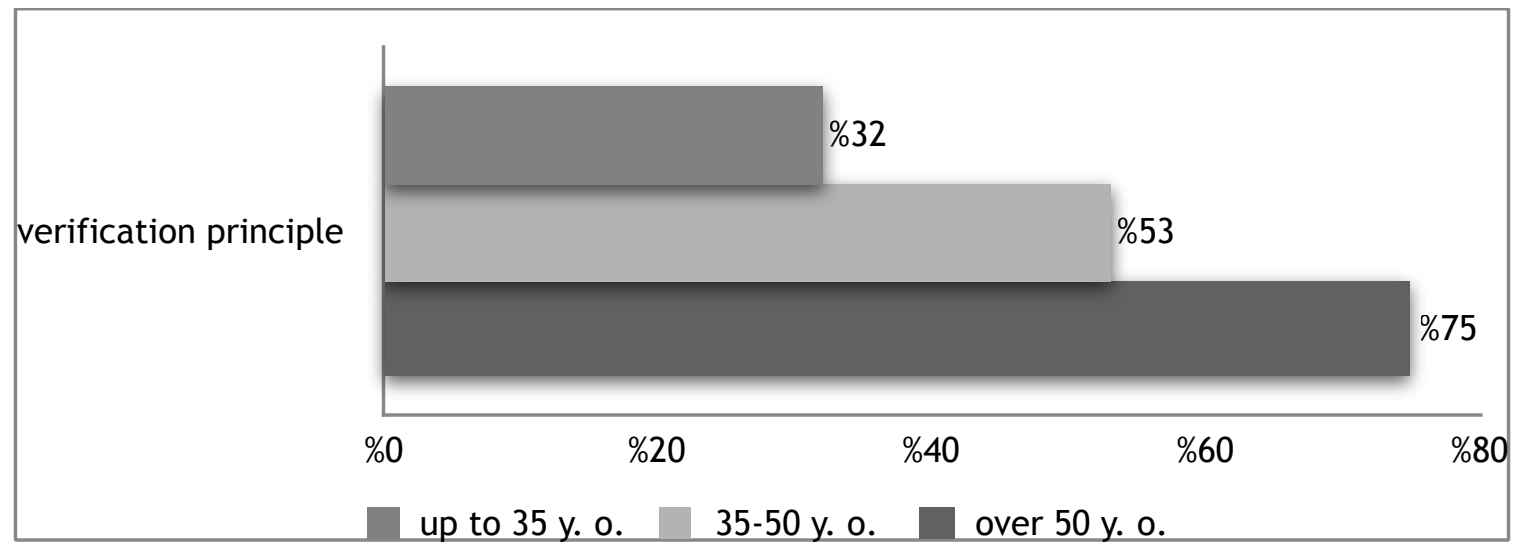

Fig.7. Distribution of respondents' answers to the question "What principles should be used to base the gamification in order to stimulate the work of teachers?" The answer is "the principle of verification" (in \% of the number of respondents in groups)

This trend is most likely connected not only and not so much with the fact that the older generation is familiar with the principle of verification on personal experience, but rather with the fact that the younger generation is afraid that the system of indicators and criteria will bureaucratize the game techniques.

In general, it seems that the primary adherence to objective principles of simplicity, verification, and feedback can have a positive effect on the use of gamification for increasing the motivation of the scientific and pedagogical staff. And the principles cannot be replaced by slogans, general provisions, indicators and obscure recommendations.

\section{DISCUSSION}

As shown by the conducted study, the majority of teachers consider gamification technologies as tools of moral labor stimulation. They believe that gamification is an effective way to increase the involvement of scientific and pedagogical staff in solving the problems facing universities. 
The fact that for any organization this is very original and interesting, moreover, a relatively economical tool of "nonmaterial" motivation is obvious for everyone. Enthusiastic employees will solve game tasks, not noticing how much effort is spent on it. According to consulting agencies, for example, Gartner, at least one game for personnel is used by $48 \%$ to $71 \%$ of global companies.

According to the results of numerous studies, gamification allows solving the following objectives quite easily, without compulsion: to increase the overall level of labor performance, to identify leaders in a particular field, to determine the development vector of each individual employee and the team as a whole, to encourage them to develop in this direction, to provide all employees with operational feedback on performance, to improve the quality of communications in the team, to reduce the number of conflicts, to unite employees with a common idea, to engage in teamwork, to inculcate employees with company values, to form an understanding of the HR brand at the level of already working employees (Kozina, 2015).

Among other things, gamification helps to facilitate the process of personnel management by simplifying rewards. Virtual awards can be tracked, accumulated, and in the end, for example, turn into significant monetary incentives. At the same time, the introduction of constant feedback (for example, the Like button on Facebook) allows people to feel that by pressing this button and leaving a positive feedback, they are really helping someone. Gamification can be enhanced by applying augmented virtual reality (Khitskov, Veretekhina, Medvedeva, Mnatsakanyan, Shmakova, \& Kotenev, 2017).

Social bonuses allow managers to encourage actions that in other cases would be very difficult to be evaluated in a monetary manner. For example, looking at the same scattered reviews, the manager can resume the indicator based on the colleagues' comments. Specific quantitative assessments can already be deduced from the total mass, comparing employees to each other. And according to the research service of HeadHunter, many organizations in 2016-2017 used/planned to use staff assessment tools to attract and retain employees (HeadHunter, 2016; 2017).

Experts from Gartner identify 4 main points by which gamification techniques control involvement: 1 Accelerated receipt/provision of feedback.

2 Clear objectives, simple and clearly defined game rules.

3 Scenarios that involve players in common processes.

4 Providing each player with a number of short-term assignments to support engagement (Melnichuk, \& Veksel, 2017).

At the same time, one should not forget that in most cases gamification is aimed at solving problems and tasks in pleasant, not stressful conditions (Surugiu, 2014, p. 65). The principle of simplicity should never be forgotten. Complex systems of scoring and verification of points, which are sometimes used, give rise to stress and rejection of gamification technologies. The same studies by HeadHunter show that organizations carefully use personnel assessment systems; and many companies do not even know how to apply them (HeadHunter, 2016).

According to the results of a survey conducted in the UK, the leaders identified the most pressing issues as lack of conviction in the economic feasibility of gamification $(81 \%)$, insufficient knowledge of its practical applicability (72\%), lack of knowledge about serious games and their advantages $(63 \%$ each), high cost of games (54\%), lack of quality information on the use of games in training (54\%) (Azadegan, Riedel, \& Haugeet, 2012). Other studies show similar results, describing as the main negative factors the existing organizational culture, the lack of a forward-looking vision for gamification technologies, the unwillingness of the top management to adopt a game culture (Petridis, Hadjicosta, Shi, Dunwell, Baines, Bigdeli, Bustinza, \& Uren, 2015).

The risks from the personnel gamification can be reduced to the following:

- A risk of devaluation of the true inner motivation of a person;

- A risk of provoking manipulation and control (ratings are perceived as a way to identify "bad" and "good" employees);

- A risk of the employee's rejection of the game rules (when the game is imposed in an orderly manner, instead of active participation, a waste of time and money is obtained). 
In order to avoid these risks, only voluntary participation in the game of employees is allowed. Control of all staff actions depresses internal motivation and the desire for autonomy and does not bring any satisfaction.

Absolute transparency of the gamification system for staff allows the staff to see goals through understanding the rules of game mechanics. Using various methods of gamification, the company management is able to retain the interest of employees, increase its internal motivation, receive timely feedback and achieve a global goal, breaking it into small ones (Zemskova, \& Krasnova, 2016).

\section{CONCLUSIONS}

Summarizing, it should be noted that most teachers are confident that the use of gamification can contribute to increasing the motivation of scientific and pedagogical staff. Moreover, despite the differences among age cohorts, modern teachers equally demonstrate a positive attitude toward gaming technology. At the same time, they note insufficient attention to this issue at the universities of Russia.

Based on the results of the study, the authors developed recommendations on the introduction of gamification for motivating teachers. In particular, special attention is paid to the following measures:

$\varnothing \quad$ Adherence to the informal approach to the issue of forming a system of moral incentives for teachers with a wide use of gamification methods.

$\varnothing \quad$ Qualified participation in the implementation of the gamification technologies of heads of scientific and pedagogical teams.

$\varnothing$ Optimization of the procedure for counting points (scores) for teachers for certain achievements.

$\varnothing \quad$ Adherence to objective principles of simplicity, verification, and feedback in the development and use of the gamification tools.

$\varnothing \quad$ Formation of organizational adherence of teachers in combination with a high degree of satisfaction with the results of their professional and research activities, including due to the relevance of the results of their activities.

$\varnothing \quad$ Expansion of the demand and practical introduction of the gamification technologies into all spheres of activity of scientific and pedagogical staff.

$\varnothing \quad$ Creation of a selection system for talented teachers, the formation of individual development programs and career development curriculum with the use of gamification evaluation systems.

Gamification is an up-to-date method of motivating teachers, which can provide positive results to the leaders of scientific and pedagogical teams. Taking into account the experience of American and European leading organizations, as well as the tendency to rejuvenate teachers, it is worth saying that gamification and the variety of its forms will certainly improve the efficiency of both all scientific and pedagogical staff and the university as a whole. At the same time, one should not forget that only with the combination of all types of motivation one can improve the effectiveness of the entire system of staff motivation, and, consequently, the company as a whole.

The authors express their gratitude to the management of the Russian State Social University and the company HeadHunter for the opportunity to conduct the sociological study, to the university professors for their participation in the survey, and for providing information on their views on the issue of using gamification for increasing the motivation of scientific and pedagogical staff.

\section{REFERENCES}

Azadegan, A., Riedel, J.C.K.H., \& Hauge, J.B. (2012). "Serious Games Adoption in Corporate Training", in Proceedings of the Third International Conference on Serious Games Development and Applications. Bremen, Germany: Springer, pp. 74-85.

Burke, B. (2014). "Gamify: How Gamification Motivates People to Do Extraordinary Things". Brookline, MA: Bibliomotion, p. 162. 
The Turkish Online Journal of Design, Art and Communication - TOJDAC ISSN: 2146-5193, September 2018 Special Edition, p.1044-1056

Dieva, A.A. (2017). "Igrovye metody v sovremennom HR-menedzhmente" ["Business Games' Techniques in Contemporary HR Management"]. Gosudarstvennoe i Munitsipalnoe Upravleniye: Uchenye zapiski, 4, 246-250. DOI: 10.22394/2079-1690-2017-1-4-246-250.

Egorychev, A.M., Mardochaev, L.V., Rybakova, A.I., Fomina, S.N., \& Sizikova, V.V. (2014). "Society and Education in the Early of XXIth Century: Integration of Tradition and Innovation". Journal of Advanced Research in Law and Economics, 5(2), 82-91.

Egorychev, A.M., Mityaeva, A.M., Fomina, S.N., \& Khovanskaya, E.A. (2017). "Integration as Condition of Sustainable Development of Society and Education", In Current Issues of Linguistics and Didactics: The Interdisciplinary Approach in Humanities (CILDIAH 2017): Proceedings of the 7th International Scientific and Practical Conference, pp. 187-193.

Fedorishcheva, T.A. (2016). "Geimifikatsiya $v$ motivatsii personala: Printsipy, metody $i$ formy" [Gamification in the Motivation of Personnel: Principles, Methods and Forms]. Problemy Razvitiya Sovremennoi Ekonomiki, 7, 12-15.

HeadHunter. (2016). "Trends in personnel evaluation market in 2016". Retrieved July 10, 2018, from: https://hhcdn.ru/file/16400572.pdf.

HeadHunter. (2017). "Key trends in personnel evaluation in 2017". Retrieved July 10, 2018, from: https://hhcdn.ru/file/16480572.pdf.

HeadHunter. (2018). "Employers and educational institutions: Goals and methods of interaction in Russia in 2018". Retrieved July 10, 2018, from: https://hhcdn.rulfile/16558580.pdf.

Ilina, I.Y., Oseev, A.A., Vinichenko, M.V., Kirillov, A.V., Kaurova, O.V., \& Nakhratova, E.E. (2018). "Transformation of Social Status of Teachers of Russian Universities". Modern Journal of Language Teaching Methods, 8(3), 381-392.

Khitskov, E.A., Veretekhina, S.V., Medvedeva, A.V., Mnatsakanyan, O.L., Shmakova, E.G., \& Kotenev, A. (2017). "Digital Transformation of Society: Entering in the Digital Economy". Eurasian Journal of Analytical Chemistry, 12(5b), 855-873. DOI: 10.12973/ejac.2017.00216a.

Kozina, E.S. (2015). "Geimifikatsiya professionalnoi deyatelnosti kak effektivnyi instrument motivatsii personala sovremennoi organizatsii" ["Gamification of Professional Activity as an Effective Tool for Motivating the Staff of a Modern Organization”]. Sovremennye problemy nauki i obrazovaniya, 2-2, 687.

Krasovsky, Yu.D., Soroko, A.V., Shemonchuk, D.S., Bondaletov, V.V., Baklanov, P.A., \& Solodova, M.V. (2018). "Simulation Modeling in Theory and Practice of Personnel Training (Visuagraphic Methodology by IU.D. Krasovskii)". International Journal of Pure and Applied Mathematics, 119(7), 905-909.

Melnichuk, Yu.A., \& Veksel, Ya.P. (2017). "Geimifikatsiya kak metod povysheniya motivatsii personala" ["Gamification as a Method to Increase Staff Motivation"], in Ekspertnoe mnenie: Sbornik statei Mezhdunarodnoi nauchno-prakticheskoi konferentsii: v 2 chastyakh [Expert Opinion: Collection of Articles of the International Scientific and Practical Conference: In 2 Parts], pp. 228-232.

Melnichuk, A.B. (2015). "Geimifikatsiya kak instrument povysheniya urovnya motivatsii personala sovremennoi organizatsii" ["Gamification as an Effective Tool for Motivating the Staff of a Modern Organization"], in Strategii sotsialnogo razvitiya sovremennogo obshchestva: rossiiskie i mirovye trendy: Sbornik materialov XIV Mezhdunarodnogo sotsialnogo kongressa [Strategies for the Social Development of Modern Society: Russian and World Trends: Collected materials of the XIV International Social Congress], pp. 318-320.

Melnichuk, Yu.A. (2016). "Geimifikatsiya kak sposob upravleniya personalom" ["Gamification as a Way of Personnel Management”]. Materialy Afanasevskikh Chtenii, 1(14), 135-139.

Melnichuk, Yu.A. (2017). "Molodye prepodavateli vuzov kak osobaya sotsialnaya gruppa (na primere vuzov g. Moskvy)" ["Young University Teachers as a Special Social Group (on the Example of Moscow Universities)"']. Sotsialnaya Politika i Sotsiologiya, 6(125).

Petridis, P., Hadjicosta, K., Shi, V.G., Dunwell, I., Baines, T., Bigdeli, A., Bustinza, O.F., \& Uren, V. (2015). "State-of-the-Art in Business Games". International Journal of Serious Games, 2, 55-69.

Rogach, O.V., Frolova, E.V., \& Ryabova, T.M. (2017). "Academic Competition: Rating Race". European Journal of Contemporary Education, 6(2), 297-307. DOI: 10.13187/ejced.2017.2.297.

Rogach, O.V., Ryabova, T.M., \& Frolova, E.V. (2017). "Social Factors of Mental Well-Being Violation among High School Teachers". European Journal of Contemporary Education, 6(4), 787-796. DOI: 10.13187/ejced.2017.4.787.

Submit Date: 10.07.2018, Acceptance Date: 22.08.2018, DOI NO: 10.7456/1080SSE/144

Research Article - This article was checked by Turnitin

Copyright (C) The Turkish Online Journal of Design, Art and Communication 
The Turkish Online Journal of Design, Art and Communication - TOJDAC

ISSN: 2146-5193, September 2018 Special Edition, p.1044-1056

Sheregi, F. E., \& Kirillov, A.V. (2017). "Trud prepodavatelya vuza: tvorchestvo ili "vyzhivanie"?" ["Higher Education Teacher's Labor: Creativity or "Survival"?"]. Sotsiologicheskie Issledovaniya, 11, 87-98. DOI: 10.7868/S0132162517110101.

Shtonda, A.S. (2017). "Geimifikatsiya kak instrument uspeshnogo upravleniya personalom" ["Gamification as a Tool for Successful Staff Management”]. Biznes-Obrazovanie v Ekonomike Znanii, 2(7), 125-131.

Surugiu, T. (2014). "Gamification as a Means for Employee Motivation, Personal Engagement and Behavioral Outcomes: A Gamification System Developers' Perspective”. Lappeenranta University of Technology, LUT School of Business, International Marketing and Management, p. 173.

Valeev, E.H.R., \& Kamasheva, A.V. (2016). "Ispolzovanie teorii geimifikatsii v povyshenii motivatsii rabotnikov" ["Theory of Gamification in Motivating Employees"]. Sovremennaya Ekonomika: Problemy i Resheniya, 10(82), 60-66. DOI: 10.17308/meps.2016.10/1506.

Vinichenko, M.V., Kirillov, A.V., Maloletko, A.N., Frolova, E.V., \& Vinogradova, M.N. (2018). "Motivation of University Authorities Aimed at Creating Favorable Learning Environment in the Course of Restructuring Higher Education Institutions". EURASIA Journal of Mathematics, Science and Technology Education, 14(5), 1899-1910. DOI: https://doi.org/10.29333/ejmste/85489.

Vinichenko, M.V., Taridi Kasbi Ridho, Kirillov, A.V., Makushkin, S.A., \& Melnichuk, A.V. (2017). "Development of Skills Management in the System Management of Talents". Modern Journal of Language Teaching Methods, 7(9), 50-57.

Werbach, K., \& Hunter, D. (2015). "Vovlekai i vlastvui. Igrovoe myshlenie na sluzhbe biznesa" ["Involve and Conquer. Game Thinking in Business"]. Moscow, Russia: Mann, Ivanov and Ferber, p. 160.

Zemskova, M.S., \& Krasnova, M.V. (2016). "Vnedrenie geimifikatsii v protsess motivatsii personala pokoleniya Y" ["Introduction of Gamification in the Process of Motivation of the Personnel of Generation Y"]. Mezhdunarodnyi Nauchno-Issledovatelskii Zhurnal, 10-1(52), 29-33. DOI: 10.18454/ IRJ.2016.52.076.

Zichermann, G., \& Linder, J. (2014). "Geimifikatsiya v biznese: kak probitsya skvoz shum i zavladet vnimaniem sotrudnikov i klientov" ["Gamification in Business: How to Break through the Noise and Get the Attention of Employees and Customers"]. Moscow, Russia: Mann, Ivanov and Ferber, p. 272. 